\title{
THE EFFECT OF GRINDING MEDIA PERFORMANCE ON WET MILLING OF CALCITE
}

\author{
${ }^{1}$ Diler KATIRCIOĞLU BAYEL \\ ${ }^{1}$ Niğgde Ömer Halisdemir Üniversitesi, Mühendislik Fakültesi, Maden Mühendisliği Bölümü, Nï̆̆DE \\ 1dkatircioglu@ohu.edu.tr
}

(Geliş/Received: 19.10.2018; Kabul/Accepted in Revised Form: 13.01.2019)

\begin{abstract}
This study aimed to conduct systematic research on the design of high-density zircon $\left(\mathrm{ZrO}_{2}\right)$ grinding media $(0.2-1 \mathrm{~mm})$ in a laboratory-scale media mill $(750 \mathrm{ml})$ for wet grinding of calcite $\left(\mathrm{CaCO}_{3}, \mathrm{~d}_{50}=5.4 \mu \mathrm{m}\right)$. Sub-micron grinding experiments were carried out by using different amounts of finer grinding media $(25 \%, 50 \%$ and $75 \%)$ and different size ratio of finer-coarser media $(0.2$ and 0.5$)$. Besides, the surface areas $\left(\mathrm{S}_{\mathrm{bw}}, \mathrm{m}^{2} / \mathrm{kg}\right)$ of grinding media on grinding performance were investigated. If the best experimental results are compared (M1 and M4), it is found that the $\mathrm{S}_{\mathrm{bw}}$ of the bimodal media (M4) is $75 \%$ larger compared to that of monosized media (M1). The experimental results were analyzed based on product size $\left(d_{50}, d_{80}\right)$, cumulative undersize curves and specific surface area $\left(\mathrm{S}_{\mathrm{w}}, \mathrm{m}^{2} / \mathrm{g}\right)$. The findings showed that only the finer grinding media was not very effective at $600 \mathrm{rpm}$.
\end{abstract}

Key Words: Calcite, Media size, Stirred media mill

\section{Kalsitin Yaş Öğütülmesinde Öğütücü Ortam Performansının Etkisi}

ÖZ: Bu çalışmada, kalsitin $\left(\mathrm{CaCO}_{3}, \mathrm{~d}_{50}=5,4 \mu \mathrm{m}\right)$ yaş öğütülmesi üzerine laboratuvar ölçekli bilyalı değirmende $(750 \mathrm{ml})$ yüksek yoğunluğa sahip zirkon $\left(\mathrm{ZrO}_{2}\right)$ bilya $(0,2-1 \mathrm{~mm})$ tasarımıla sistematik bir çalışma amaçlanmıştır. Farklı miktarda ince bilya (\%25, \%50 ve \%75) ve farklı ince-iri bilya oranları (0,2 ve 0,5$)$ kullanılarak mikron-altı öğütme gerçekleştirilmiştir. Ayrıca, öğütücü ortamın yüzey alanlarının $\left(\mathrm{S}_{\mathrm{bw}}, \mathrm{m}^{2} / \mathrm{kg}\right.$ ) öğütme performansına etkisi araştırılmıştır. En iyi deney sonuçları karşılaştırıldığında (M1 ve M4), karışık bilya boyut dağılımının (M4) yüzey alanı, tek tip bilya boyut dağılımının (M1) yüzey alanından \%75 daha fazladır. Deneysel sonuçlar ürün boyutu $\left(\mathrm{d}_{50}, \mathrm{~d} 80\right)$, kümülatif elek altı eğrisi ve spesifik yüzey alanı $\left(\mathrm{S}_{\mathrm{w}}, \mathrm{m}^{2} / \mathrm{g}\right)$ dikkate alınarak değerlendirilmiştir. Sonuçlar, sadece ince boyutlu öğütücü ortamın 600 devir/dk hızda çok fazla etkili olmadığını gösteriyor.

Anahtar Kelimeler: Bilya boyutu, Kalsit, Karıştırmalı bilyalı değirmen

\section{INTRODUCTION}

Grinding is an important particle size reduction method that is used widely in various industries. Nowadays, the necessity for so-called submicron particles and nanoparticles sizes keeps on rising in industries such as paints, ceramics, water proofing materials, mining with a developing technology. Researchers have studied several strategies to achieve better submicron and nano grinding performance (Cho et al., 2009; Kumar et al., 2010; Vital et al., 2001; Yokoyama and Huang et al., 2005; Patel et al., 2014). The product size characteristics of mills are mostly affected by media size (Mankosa et al., 1989; Kwade et al., 1996; Patel et al., 2014; Bel Fadhel and Frances, 2001; Wang and Forssberg, 2007).

Coarser grinding media exert high stress intensity in comparison to finer media at the same media filling ratio and stirring speed parameters. However, finer grinding media, due to their high number, increase the number of collisions (Kwade et al., 1996; Bel Fadhel and Frances, 2001). Bilgili et al. (2004) 
reported that the use of mixed media sizes leads to improvement of nano grinding performance. If coarser grinding media are used for finer feed, this causes usage of a lot of energy. On the other hand, when finer grinding media are used for coarser feed, the transfer of stress energy is decreased. Finer grinding media cause faster size reduction but profit and loss accounts should be considered (Bel Fadhel and Frances, 2001). Nevertheless, coarser grinding media are more susceptible to wear than finer media, although their cost is lower in comparison to finer media (Breitung-Faes and Kwade, 2008). To obtain the desired particle size and optimize energy efficiency, one of the most useful techniques is to utilize coarser grinding media for coarser feed and finer media for finer feed (Wang and Forssberg, 2007).

This study, examined whether or not an improvement in submicron grinding performance of calcite may be achieved by using monosized and bimodal size media. Grinding experiments were conducted on calcite by using different combinations of grinding media sizes. The experiments were carried out by finer to coarser grinding media size ratio (0.2 and 0.5$)$ and different amounts of finer grinding media (25 $\mathrm{wt} . \%, 50 \mathrm{wt} . \%$ and $75 \mathrm{wt} . \%)$. The grinding results were evaluated by four parameters as product particle sizes $\left(\mathrm{d}_{50}, \mathrm{~d}_{80}\right)$, cumulative particle size and specific surface area $\left(\mathrm{S}_{\mathrm{w}}\right)$.

\section{MATERIAL AND METHOD}

\section{Material}

Calcite $\left(\mathrm{CaCO}_{3}, \mathrm{~d}_{50}=5.4 \mu \mathrm{m}\right)$ powders that were obtained from Mikron's (Nigde, Turkey) were used for the experiments. Table 1 shows the chemical compositions of the calcite feed measured by X-ray fluorescence (XRF), while Table 2 shows the physical characteristics of the calcite feed.

Table 1. The chemical composition of the calcite measured by XRF analysis (wt.\%)

\begin{tabular}{llllll}
\hline $\mathrm{CaCO}_{3}$ & $\mathrm{MgCO}_{3}$ & $\mathrm{SiO}_{2}$ & $\mathrm{Fe}_{2} \mathrm{O}_{3}$ & $\mathrm{Al}_{2} \mathrm{O}_{3}$ & $\mathrm{LOI}\left(1050 \mathrm{C}^{\circ}\right)$ \\
\hline 99.5 & 0.2 & 0.01 & 0.01 & 0.02 & 0.26
\end{tabular}

Table 2. Physical characteristics of the calcite feed

\begin{tabular}{cccccc}
\hline $\begin{array}{c}\text { Specific } \\
\text { gravity }\left(\mathrm{kg} / \mathrm{m}^{3}\right)\end{array}$ & $\begin{array}{c}\text { Mohs } \\
\text { hardness }\end{array}$ & $\begin{array}{c}\text { Refractive } \\
\text { index }\end{array}$ & $\begin{array}{c}\mathrm{d}_{50} \\
(\mu \mathrm{m})\end{array}$ & $\begin{array}{c}\mathrm{d} 80 \\
(\mu \mathrm{m})\end{array}$ & $\begin{array}{c}\text { Specific surface } \\
\text { area } \\
\left(\mathrm{m}^{2} / \mathrm{g}\right)\end{array}$ \\
\hline 2700 & 3.0 & 1.59 & 5.4 & 13 & 2.26 \\
\hline
\end{tabular}

A pycnometer was used to determine the specific gravity of the calcite powders and found it to be $2700 \mathrm{~kg} / \mathrm{m}^{3}$. Figure 1 shows the result of the XRD pattern analysis of the calcite. As compared to the Joint Committee Powder Diffraction Standards (JCPDS), the main chemical component of the calcite was $\mathrm{CaCO}_{3}$ 


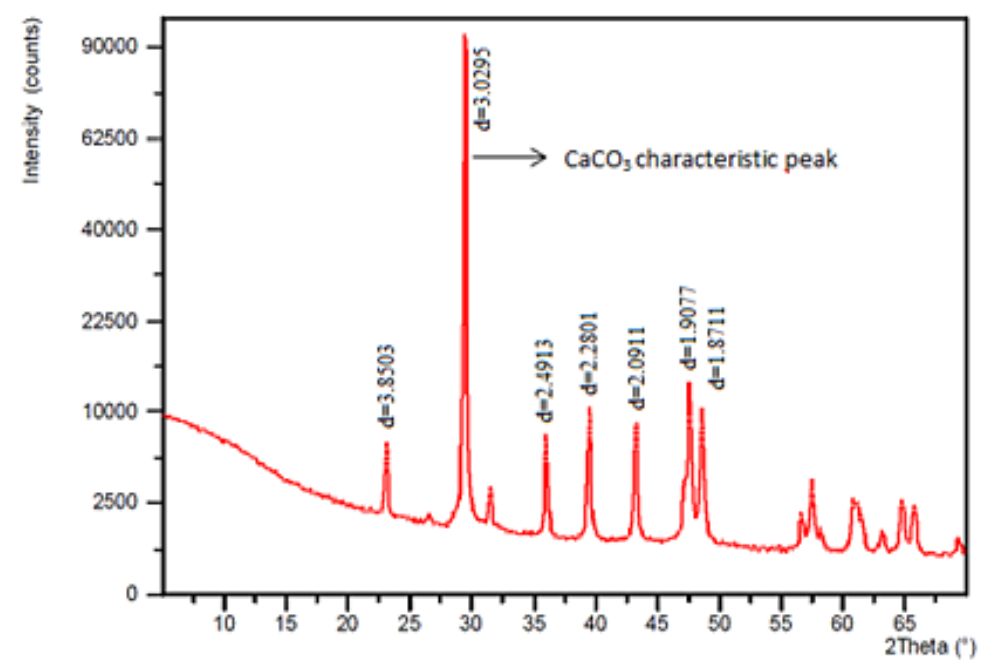

Figure 1. XRD pattern of feed calcite

Moreover, as dispersant, an amine-based grinding aid, which is commonly used in the calcite industry was selected. The density of this chemical is $1.13 \pm 0.02 \mathrm{~g} / \mathrm{cm}^{3}$, and it was used to disperse the particles of $\mathrm{CaCO}_{3}$ in water. The chemical additive concentration was kept constant at $0.5 \%$ of calcite. Pure water was used for preparation of all suspensions. The high-density $\left(6000 \mathrm{~kg} / \mathrm{m}^{3}\right)$ yttria stabilized zirconia $\left(\mathrm{ZrO}_{2}\right)$ grinding media (chemical composition: $93 \% \mathrm{ZrO}_{2}, 5 \% \mathrm{Y}_{2} \mathrm{O}_{3}$ and $2 \%$ others) that were utilized for the submicron grinding tests were purchased from Cenotec Co., Ltd., Korea.

\section{Method}

The grinding experiments were conducted in a vertical stirred media mill Standard-01 Model produced by Union Process (U.S.A.). The milling chamber had a net volume of $750 \mathrm{ml}$. For minimizing the amount of wear on the mill from the materials, the grinding chamber was made of ceramic $\left(\mathrm{Al}_{2} \mathrm{O}_{3}\right)$. For cooling purposes, the grinding chamber was also equipped with a water jacket. The experimental conditions that were used in this study may be seen in Table 3. For example, M2 was carried out with a finer to coarser media size ratio of 0.5 by mixing $25 \mathrm{wt} . \%$ of finer $(0.5 \mathrm{~mm})$ grinding media into coarser media $(1 \mathrm{~mm})$. This study, considered the grinding media size of $(1 \mathrm{~mm})$ as coarser media, while grinding media of sizes $0.5 \mathrm{~mm}$ and $0.2 \mathrm{~mm}$ were considered as finer media. Different proportions of 25 wt.\%, $50 \mathrm{wt.} \%$, and $75 \mathrm{wt} . \%$ finer media were used. The solid mass fraction, stirrer speed, dispersant concentration, grinding media loading and grinding time were fixed at $20 \%, 600 \mathrm{rpm}, 0.5 \mathrm{wt} . \%, 60 \%$ and $60 \mathrm{~min}$, respectively. 
Table 3. Experimental conditions used in the different runs

\begin{tabular}{lccc}
\hline Run number & $\begin{array}{c}\text { Grinding media } \\
\text { size }(\mathrm{mm})\end{array}$ & $\begin{array}{c}\text { Size ratio finer to coarser } \\
\text { grinding media }\end{array}$ & $\begin{array}{c}\text { Proportion of finer } \\
\text { grinding media (wt.\%) }\end{array}$ \\
\hline M1 & 1 & 0 & 0 \\
M2 & $1+0.5$ & 0.50 & 25 \\
M3 & $1+0.5$ & 0.50 & 50 \\
M4 & $1+0.5$ & 0.50 & 75 \\
M5 & 0.5 & 1 & 100 \\
M6 & $1+0.2$ & 0.2 & 25 \\
M7 & $1+0.2$ & 0.2 & 50 \\
M8 & $1+0.2$ & 0.2 & 75 \\
M9 & 0.2 & 1 & 100 \\
\hline
\end{tabular}

\section{Analysis}

A Laser Diffraction Particle Sizer Malvern 2000 Ver. 2.00 (Malvern Co., Ltd., UK) was used to analyze the calcite feed and the ground product sizes and specific surface areas. Before determining particle size, for the measurement, samples of the suspensions were diluted and dispersed via ultrasound in $800 \mathrm{ml}$ pure water. Each test had three replications. The results of the measurements are reported as average values. The X-ray fluorescence (XRF) analysis of the feed was carried out using a ZSXminill X-ray Spectrophotometer. PANalytical Empyrean was used to recover X-ray diffraction (XRD) patterns and examine the crystal buildup of the powder that was ground. Patterns in the diffraction angle range of $2 \Theta=5-70^{\circ}$ were recorded by using Ni-filtered $\mathrm{CuK} \alpha(\lambda=0.15418 \mathrm{~nm})$ radiation with a measuring time of $8 \mathrm{~s}$ at each angle. A Zeiss Evo LS 10 microscope was used to obtain the SEM pictures of the calcite feed and the ground product.

\section{RESULTS AND DISCUSSION}

\section{Effect of Monosized and Bimodal Media Size on Submicron Grinding of Calcite}

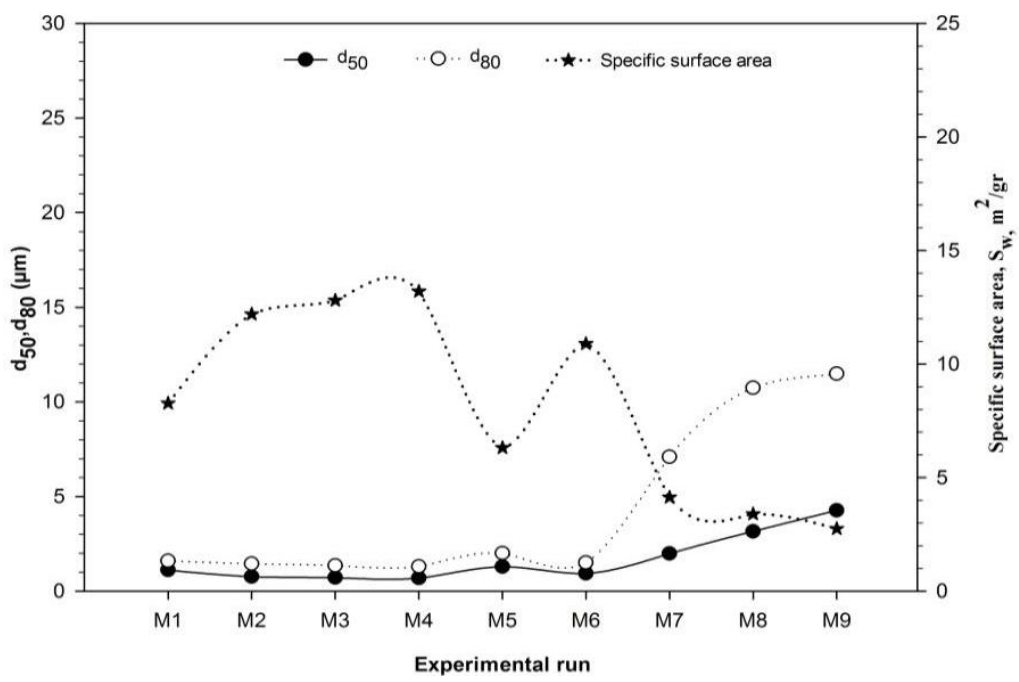

Figure 2. $d_{50}, d_{80}$ and specific surface area $\left(S_{w}\right)$ as a function of bimodal and monosized media

In Figure 2, the $\mathrm{d}_{50}, \mathrm{~d}_{80}$ and specific surface area are shown as a function of bimodal and monosized media. When grinding experiments were carried out with coarser media $(1 \mathrm{~mm})$, the mean particle size $\left(\mathrm{d}_{50}\right)$ was obtained as nearly $1.1 \mu \mathrm{m}$ (M1). When $25 \mathrm{wt}$.\% of finer media of size $(0.5 \mathrm{~mm})$ was combined with $1 \mathrm{~mm}$ media, the particle size that was obtained about $0.7 \mu \mathrm{m}(\mathrm{M} 2)$. When the coarser media were 
mixed with higher amounts of finer media, the observed results were improved (M3 and M4). This clearly revealed that addition of finer media improved the grinding performance. By adding higher ratios of finer $(0.5 \mathrm{~mm})$ media to coarser media $(1 \mathrm{~mm})$, further improvements were obtained the grinding results (M4). The mean particle size, $\mathrm{d}_{80}$ and specific surface area were obtained as $0.68 \mu \mathrm{m}, 1.3$ $\mu \mathrm{m}$ and $13.2 \mathrm{~m}^{2} / \mathrm{gr}$, respectively. The mean particle size of about $1.3 \mu \mathrm{m}$ was obtained in M5. However, when 25-50-75 wt.\% of finer media of size $0.2 \mathrm{~mm}$ was mixed $1 \mathrm{~mm}$ media, the product sizes increased (M6-7-8). The mean particle size of about $3.2 \mu \mathrm{m}$ was obtained in M8. When grinding was carried out with only the finer media size of $0.2 \mathrm{~mm}$, the mean particle size was about $4.3 \mu \mathrm{m}$ (M9). Figure 3 shows the cumulative particle size distribution of calcite under different experimental conditions. The best results were provided by M4 in terms of particle size.

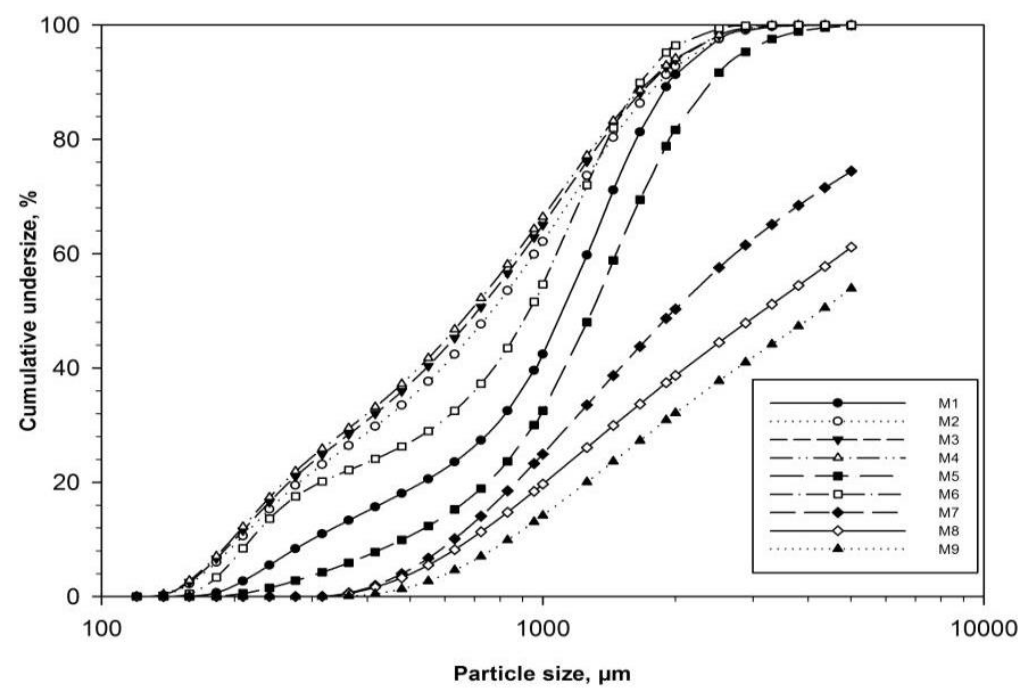

Figure 3. Cumulative particle size distribution under different experimental conditions

Figure 4 shows the effects of monosized media $(0.2,0.5$ and $1.0 \mathrm{~mm})$, (M1, M5 and M9) on the particle size distribution. M1 provided the best mean particle size.

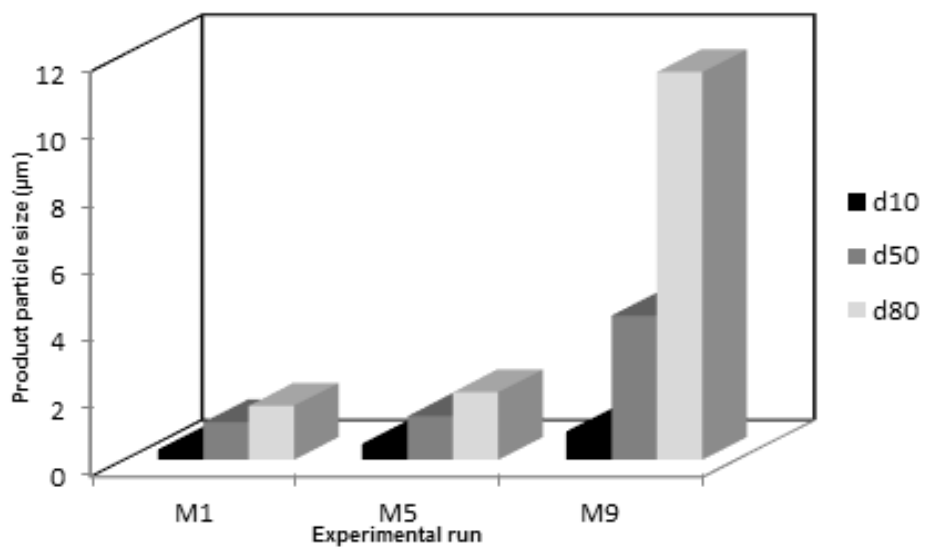

Figure 4. Effect of monosized grinding media on product particle size of calcite

By creating high energy intensity, stirrer speed increases the possibility of media-particle collision in the main chamber. When finer media were used under a lower speed, there was very little effect.

As a result of the experimental studies conducted by Tüzün (1994) and Yue et al. (2006), while it was more efficient to use coarser grinding media in comparison to finer grinding media at low stirrer speeds, 
it was more efficient to use finer grinding media in comparison to coarser grinding media at high stirrer speeds.
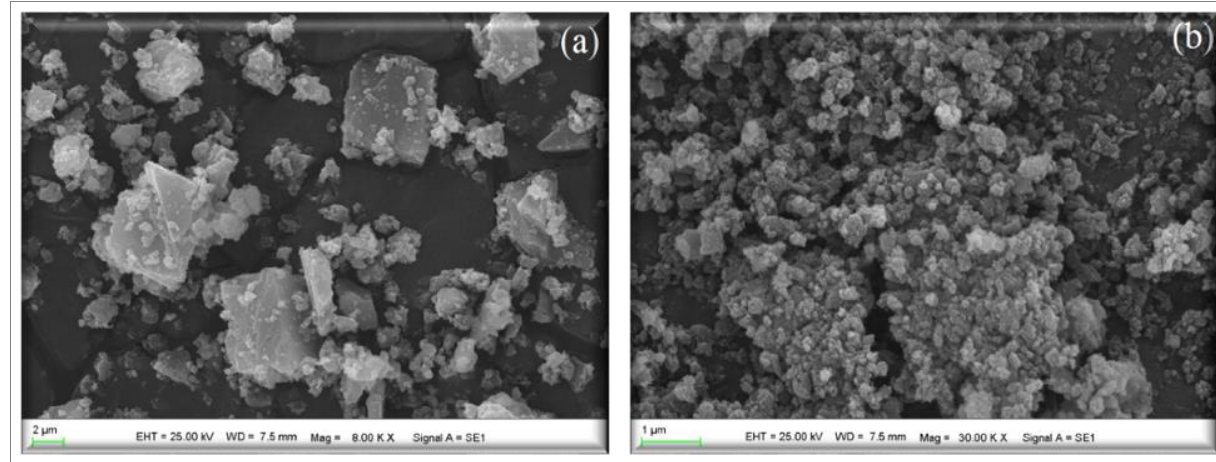

Figure 5. Scanning electron micrographs of calcite: (a) feed and (b) the best result (M4)

\section{Effect of Surface Area of Grinding Media on Submicron Grinding Process}

Calculation of the surface area for monosized and bimodal grinding media were evaluated using Eq. 1. The surface area $\left(\mathrm{m}^{2} / \mathrm{kg}\right)\left(\mathrm{S}_{\mathrm{bw}}\right)$ derived from Kotake et al. (2014) is:

$$
S_{b w}=\frac{6}{\rho} \sum_{i=1}^{n} \frac{f_{i}}{D_{b i}}
$$

Where $S_{b w}\left(\mathrm{~m}^{2} / \mathrm{kg}\right)$ is the surface area for monosized and bimodal grinding media, $\mathrm{D}_{\mathrm{bi}}$ is the media diameters, $f_{i}$ is the mass fraction for each media diameter, and $\rho\left(\mathrm{kg} / \mathrm{m}^{3}\right)$ is the true density of grinding media.

The most effective grinding in the media mill was achieved by an increased number of collisions between grinding media and particles. Figure 6 shows the experimental run versus surface area ( $\left.\mathrm{S}_{\mathrm{bw}}\right)$. From the results, maximum surface area ( $\left.\mathrm{S}_{\mathrm{bw}}\right)$ was obtained with experimental run M9. But when finer media was used at a lower speed, the effects on particle size were very little. If the best experimental results are compared (M1 and M4), it is found that the $S_{b w}$ of the bimodal media (M4) is $75 \%$ larger compared to that of monosized media. 


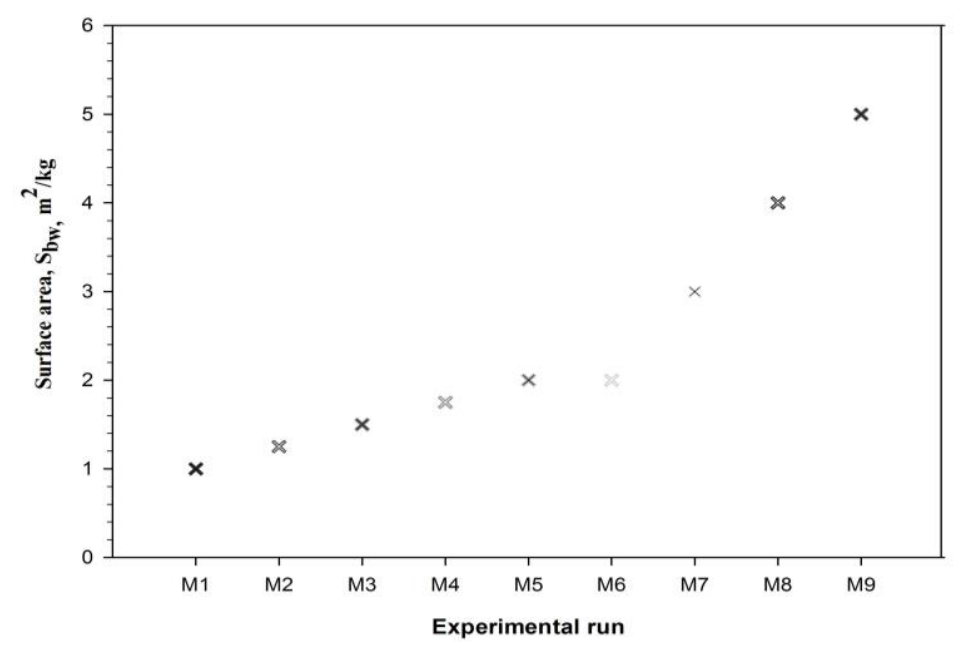

Figure 6. Surface area $\left(S_{b w}\right)$ for monosized and bimodal grinding media

\section{CONCLUSION}

In this study, the influence of monosized $(0.2,0.5$ and $1.0 \mathrm{~mm})$ and bimodal $(0.2-1 \mathrm{~mm})$ media size grinding design on wet grinding of calcite were investigated. The performance of finer to coarser grinding media size ratio of 0.2 and 0.5 were analyzed. The grinding tests carried out with stirred media mill showed that:

- Experimental results show that only the finer grinding media was not very effective at $600 \mathrm{rpm}$. Much smaller product particles with finer grinding media can be obtained with a high stirrer speed.

- Proper selection of media size improves the grinding efficiency.

- The optimum conditions for the grinding performance were obtained with bimodal media (M4) and average particle size $\left(\mathrm{d}_{50}\right)$ is $0,68 \mu \mathrm{m}$.

- If the best experimental results are compared (M1 and M4), it is found that the Sbw of the bimodal media (M4) is 75\% larger compared to that of monosized media (M1).

\section{REFERENCES}

Bel Fadhel, H. and Frances, C., 2001, "Wet batch grinding of alumina hydrate in a stirred bead mill", Powder Technology, 119, (2-3), 257-268.

Bilgili, E., Hamey, R., Scarlett, B., 2004, “Production of Pigment Nanoparticles Using a Wet Stirred Mill with Polymeric Media", China Particuology, 2, 93-100.

Breitung-Faes, S. and Kwade, A., 2008, "Nano particle production in high-power-density mills" Chemical Engineering Research and Design, 86, 4, 390-394.

Cho, K., Chang, H., Kil, D. S., Kim, B. G., Jang, H. D., 2009, "Synthesis of dispersed CaCO3 nanoparticles by the ultrafine grinding", Journal of Industrial and Engineering Chemistry, 15, 243246.

Kotake, N., Matsumoto, K., Sekine, Y., Gunj1, S., Kezuka, H., 2014, “Effect of Poly-sized and Mono-sized Grinding Media on Fine Grinding of Limestone in a Bead Mill", International Journal of the Society of Materials Engineering for Resources, 20, 147-153.

Kumar, P., Sahoo, B. K., De, S., Kar, D. D., Chakraborty, S., Meikap, B. C., 2010, “Iron ore grindability improvement by microwave pre-treatment", Journal of Industrial and Engineering Chemistry, 16, 805-812.

Kwade, A., Blecher, L., Schwedes, J., 1996, "Motion and stress intensity of grinding beads in a stirred media mill: Part II. Stress intensity and its effect on comminution", Powder Technology, 86, 6976 . 
Mankosa, M. J., Adel, G. T. and Yoon, R. H., 1986, “Effect of media size in stirred ball mill grinding of coal", Powder Technology, 4, 75-82.

Patel, C. M., Chakraborty, M., Murthy, Z. V. P., 2014, "Enhancement of stirred media mill performance by a new mixed media grinding strategy", Journal of Industrial and Engineering Chemistry, 20, 2111-2118.

Tüzün, M. A., 1994, "A study of comminution in a vertical stirred ball mill", Ph.D. Dissertation, Chemical Engineering Department, University of Natal.

Vital, A., Zurcher, S., Dittmann, R., Trottmann, M., Lienemann, P., Bommer, B., Graule, T., Fadhel, H. B., Frances, C., 2001, "Wet batch grinding of alumina hydrate in a stirred media mill", Powder Technology, 119, 257-268.

Wang, Y., Forssberg, E., 2007, “Enhancement of energy efficiency for mechanical production of fine and ultra-fine particles in comminution", China Particuology, 5, 193-201.

Yokoyama, T., Huang, C. C., 2005, "Nanoparticle technology for the production of functional materials", Kona, 23, 7-17.

Yue, J., and Klein, B., 2006, "Effects of bead size on ultrafine grinding in a stirred bead mill", Advances in Comminution, Kawatra S. (ed.), Society for Mining, Metallurgy and Exploration, Inc. 